\title{
Translating children's literature of Ukrainian Diaspora as an implementation of the educational ideal of Ukrainian abroad \\ Maryna Vardanian*
}

Kryvyi Rih State Pedagogical University, Department of Foreign Languages, 54 Gagarina Ave., Kryvyi Rih, 50086, Ukraine

\begin{abstract}
This essay examines the implementation of the educational ideal of Ukrainian Abroad in the Ukrainian Diasporic translation of children's literature by such authors as Dhan Gopal Mukerji, Louis Henri Boussenard, Oscar Wilde, Daniel Defoe, Rudyard Kipling, etc. I claim that this ideal was formed in the $20^{\text {th }}$ century in different cultural centers, united by Ukrainian World Congress. The Second Ukrainian World Congress approved main principles of the educational ideal in 1973, summarizing previous achievements. It is based on such human values as love, respect, and tolerance. All of these values got a Ukrainian sense. My focus in this article is on how these principles of the educational ideal are fulfilled in the translation of children's literature of Ukrainian Diaspora.
\end{abstract}

\section{Introduction}

The subject of the Ukrainian educational ideal is relevant for Ukrainian modern society. This issue is enunciated in The New Ukrainian School, the policy document of the Ministry of Education and Science of Ukraine, the conceptual principles of which are based on the viewpoint that Ukrainian school leaver is a personality, patriot, and innovator. The first element includes the notion of a fully developed all-round personality, capable of critical thinking. The second element relates to the development of a patriot taking an active role, acting according to ethical principles and capable of making responsible decisions, respecting the dignity and the rights of people. The third element reveals a school leaver's ability to change the world around him / her. Thus, these components need a meaningful filling. In this regard, teachers are given a creative freedom to choose approaches for that purpose [1].

For the realization of the second component, namely the development of a patriot, it is considered expedient to examine the experience of Ukrainians abroad. Living in exile, outside of Ukraine, these Ukrainians remained the patriots of their country, and actively implemented the concept of the educational ideal at different levels of material and spiritual culture. These are Ukrainian cultural centers, schools, universities, archives, museums, churches, and a creative heritage (such as pedagogical articles, literature, including translated literature for children, etc.).

The goal of the article is to trace the implementation of the educational ideal of Ukrainian in the translated children's literature.

\section{Bibliography analysis on the issue}

The issue was not a special subject of research of Ukrainian scientists. Some of its aspects were considered in the monograph The Self - the Other in the Children's Literature of the Ukrainian Diaspora: National Sphere of Concepts, Imagological Models [2]. Moreover, O. Dzhus studied the national and patriotic education of children and youth in Ukrainian Diaspora in her National Patriotic Education of Children and Youth in Ukrainian
Diaspora: Experience, Attempts of Rethinking [3]. The researcher examined the issue of the educational ideal of Ukrainian abroad in the works Nationalism and Internationalism in an Educational by S. Rusova, The Educational Ideal by H. Vashchenko, Native Language and Intellectual Development of Children by V. Simovych, The Psycho-didactic Aspects of Ukrainian Education in Diaspora by O. Kulchytskyi, Ukrainian Nature and our Educational Ideal by V. Yaniv, etc. They were mainly Ukrainian teachers, and scientists, who emigrated during the second wave (between the two world wars in the $20^{\text {th }}$ century), or the third wave after World War II (these emigrants were named the generation of the Second World War). Hence, issues of their heritage include the study of the place and role of the native language; national and cultural heritage in the education of the young generation of Ukrainians; building national school; comprehension of foreign pedagogical ideas, etc.

Similar issue was the subject of the dissertation Ukrainian Pedagogical Press of Canada as the Factor of Development of Native Language Education in Diaspora (second half of the $20^{\text {th }}$ century) by $\mathrm{H}$. Byhar. There, she examines the development of Ukrainian school and pedagogical idea in Ukrainian Diaspora of Canada [4]. In particular, the researcher analyzed the Ukrainian Diasporic teachers' works, which highlighted the role of native language for human, society, and nation, its purpose for ethnic community in Diaspora.

Another aspect of my research is a collaboration of children's literature and translation. Actually, it is a general scientific issue that was not detailed in Ukrainian scientific works, but some of its components were explored by foreign researchers such as Emer O'Sullivan in Comparative Children's Literature, Ritta Oittinen in Translating for Children, G. Klingberg in Children's Fiction in the Hands of the Translator, etc. The Routledge Companion to translation studies published the collection entitled Handbook of Translation Studies.

Gillian Lathey, and Cecilia Alvstad studied the issue in the articles of the handbooks. "Translation of children's literature is characterized by a series of traits", emphasized C. Alvstad. Among these, she defined the

* Corresponding author: maryna.vardanian@gmail.com 
most common subjects treated by scholars in the field: cultural context adaptation, and ideological manipulation [5]. The approach named 'cultural context adaptation' by G. Klingberg includes domestication of foreign names, coinage and foodstuffs, literary references, foreign languages, historical background, flora and fauna, and other culture-specific phenomena.

Translation strategy of ideology in the adoptation attracted the attention of a number of scholars. "Fernández López (2000) discusses intercultural ideological factors in the translation into Spanish of the work of Roald Dahl and Enid Blyton. The eradication of racist and sexist language from the work of these authors during the 1970s and 1980s was ignored in Spanish translations that returned to earlier, 'unpurified' versions of source texts, thereby creating a mismatch between English and Spanish versions published in the same period," said G. Lathey in her Children's Literature [6]. Such adaptations called "purification" by G. Klingberg, is translation which is adapted to adhere to the adults' (parents', teachers', etc.) supposed sets of values [5].

Here, I will not discuss all of these works in detail. It is a subject of another research. On the one hand, national and patriotic education was a cross-cutting and important issue for Ukrainian emigrants, who sought to preserve their national identity outside of Ukraine. On the other hand, Ukrainian translators used both approaches, which I mentioned before.

Therefore, in this article I wonder about the principles of the educational ideal that were formed by the Ukrainian Diaspora and how they were implemented in the translated children's literature.

In this connection, it should be emphasized that I chose the translation of children's literature of Ukrainian Diaspora for several reasons. Firstly, the formation of personality begins from childhood. In this process, children's literature played the major role for Ukrainian Diaspora. Secondly, Ukrainians abroad were learning the world's best experience, using its practices through the translated literature. Thirdly, Ukrainian Diaspora interpreted human values of the best world writings for children, using Ukrainian senses.

Thus, the translators realized in translated children's literature the national and spiritual basics of Ukrainian identity or mentality, their vision of the world picture. To this effect, my essay consists of two parts, following as:

(1) the concept of the educational ideal of Ukrainian, its formation in Diaspora;

(2) the implementation of the educational ideal of Ukrainian in translated literature for children and youth.

\section{The formation of the concept of educational ideal of Ukrainian Abroad}

In different periods of the $20^{\text {th }}$ century, the Ukrainian Diaspora established different centers in the countries of its new settlement. (Fig. 1). Cultural community consolidated in these centers, which included such organizations as:

- educational institutions (in particular, kindergartens, Ukrainian Saturday Schools, universities such as
Ukrainian Free University, and Canadian Institute of Ukrainian Studies),

- scientific institutions (in particular, Ukrainian Free Academy of Sciences, Shevchenko Scientific Society, etc.);

- youth unions and movements, including Plast (Ukrainian Scouting Organisation), CYM (Ukrainian Youth Association), etc.;

- women organizations (for example, Union of Ukrainian Americans, Canada, etc.);

- literary associations (in particular, Ukrainian Writers' Association in exile "Slovo", Leonid Hlibov Association of Children's Literature).

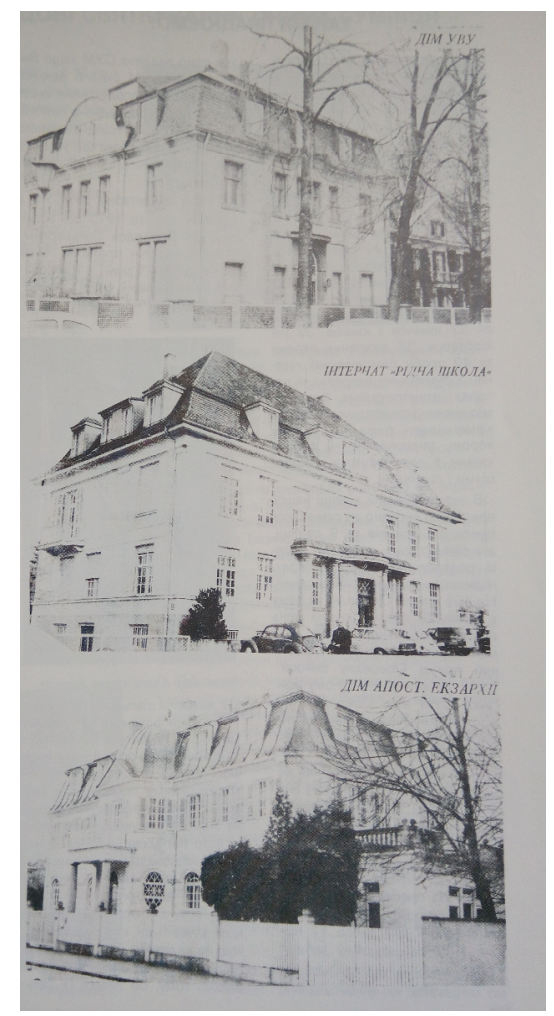

Fig. 1. The cultural centers in Munich (top - the building of Ukrainian Free University; middle - the building of "Ridna Schkola" ("Native School"); bottom - the building of Exarchy's Apostle)

The primary task of these centers was to preserve national, cultural and religious identity, crafts and traditions of Ukrainian people. These organizations unite into the Ukrainian World Congress. The Ukrainian World Congress has the World Coordination Educational Council, which aim is to coordinate the educational process in the Diaspora.

Here, I primarily turn to Leonid Hlibov Association of Children's Literature, because it is related to both notions of the article, including the educational ideal and translating literature. First of all, the Association was founded at the conference of writers and teachers, held on March 26-27, 1946 near Munich (Germany). As provided in the association's Statute, its members should create a magazine for children and periodicals on issues about children's literature and pedagogy; publish original (native) and translated children's books; call for teachers, parents and community to unite and work for Ukrainian children (taken from the collection of 
TsDAZU in Ukraine - The Central State Archive of Foreign Ukrainica).

The association's members were both writers and teachers, and all of them worked for the same purpose, namely the formation of the educational ideal of Ukrainian abroad.

The pedagogical line was implemented, in particular, in the magazine Ukrainian School. In addition to the resolutions of Leonid Hlibov Association of Children's Literature, it covered information on methodological teacher's conferences and congresses, as well as statistics of Ukrainian schools in Germany at that time.

However, its main aim was to discuss various issues in theory, history and methodology of learning. The magazine was published in 1947-1948 in Augsburg, Germany. Now it is a rarity edition and a valuable find for researchers of the history of Ukrainian pedagogy (Fig. 2).

The national and patriotic issues were widely discussed in the magazine, in particular, in such articles and reports as $A$ teacher-national and the principles of his / her work by prof. Leonid Biletskyi (Ukrainian School, 1947), Educational issue of our nowadays by prof. Borys Lysianskyi (Ukrainian School, 1948), The Concept of Ukrainian Human as the Educational Ukrainian Ideal by prof. Oleksandr Kulchytskyi (Ukrainian School, 1948). Thus, according to the emigrants of that time, the Ukrainian educational ideal is "a universal human ideal taken through Ukrainian perception," O. Kulchytskyi says [7].

Another magazine by Leonid Hlibov Association of Children's Literature is We and Our Children. The newsletter was first published in the second half of $20^{\text {th }}$ century in Toronto, Canada and New York, USA. Here, the issues of literary text were considered through the moral, ethical, national and patriotic upbringing (Fig. 3).

The children's literature had a special role in this magazine. In particular, it was considered as a spiritual and patriotic inspirer for Ukrainian children and young adult of the Diaspora. Actually, the literature was called the "literature with mission", which aim was to educate the true patriot of Ukraine's future.

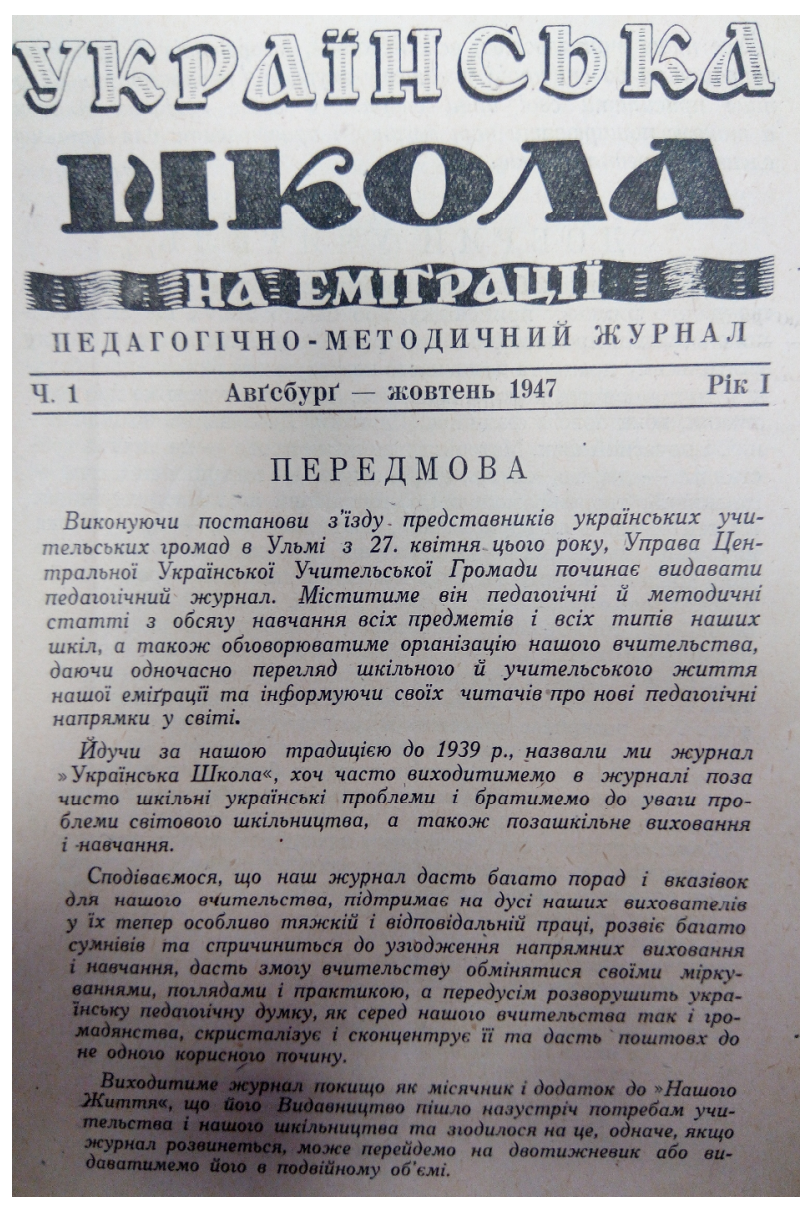

Fig. 2. The title of the first number of the magazine Ukrainian School (Germany, 1947)

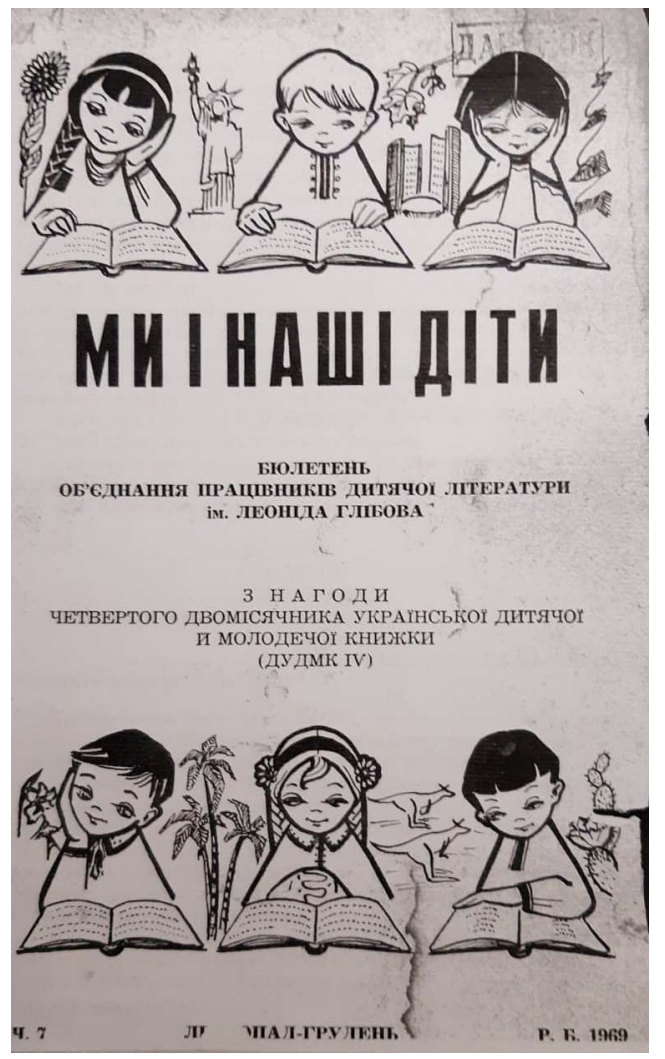

Fig. 3. The title of the newsletter by Leonid Hlibov Association of Children's Literature (Toronto, 1969) 
One of the ideologists of Leonid Hlibov Association of Children's Literature B. Hoshovskyi in his articles proclaimed that "the soul of a Ukrainian child" is a fundamental value of Ukrainian nation in children's literature of Ukrainian Diaspora, and "a writer is the creator of the soul" [8].

This point was reflected in the choice of heroes and motifs. The images had to implement the aesthetic concept of human in the artistic world of Ukrainian Diasporic writers. This aesthetic concept was based on the idea of the educational ideal of the Ukrainian. Similarly, motifs had to express themselves in the preservation and continuation of the national idea. Therefore, the educational idea and poetic form were combined in the writings of Ukrainian Diasporic children's literature. Such combination means, on the one hand, the preservation of Ukrainian literary traditions, keeping in touch with the historical Motherland, on the other hand, it is an ensuring continuity and sustainable development of the Ukrainian idea.

Actually, the idea of the educational ideal of the Ukrainian in the Diaspora was approved at the Second World Congress of Free Ukrainians (Toronto, Canada, 1973). However, the work on the concept had started in 1967 by the just-established World Coordination Educational Council. According to the materials of the Second World Congress of Free Ukrainians (Toronto New York, 1986) the idea of the educational ideal is based on the following principles:

1) love for the native Ukrainian language and culture heritage;

2) respect to the national and personal dignity of Ukrainians;

3) Christian tolerance as the antithesis of class struggle;

4) ethical and moral values as the antithesis of the current trends of materialism, atheism, nihilism;

5) respect and tolerance to the cultures of the new settlement.

This idea was detailed in the monograph Parents and Children by Antonina Horokhovych, the leader of the teachers' movement of the Ukrainians of Canada, and writer. As the researcher concludes, "the purpose of Ukrainian education is a human, who is nationally conscious, has a strong character, is not assimilated, but spiritually rich, all of which is drawn from ancestral culture. As the spiritually rich personality, he / she is the bearer of the idea, and lives with understanding that he / she needs to share his / her spiritual goodness with others" [9]. Together with Ukrainian Diasporic writers, A. Horokhovych emphasized that the educational ideal of the Ukrainian was reflected in literature.

\section{The implementation of the educational ideal of Ukrainian in translated literature for children and youth}

Translating children's literature had an important role for Ukrainian Diaspora of the $20^{\text {th }}$ century, who actively translated the world literature. When Diasporic Ukrainians were outside of their Motherland, they discovered the culture and language of the countries of their new settlement. The new reality influenced the writers' works. On the one hand, these writings reproduced the understanding of the world of the other culture, and on the other hand, they were related to the idea of the abandoned Motherland, and discovered the Ukrainian mental, national and spiritual world.

In its connections with the culture of various nations, the literature played several roles. B. Hrinchenko talked about two of them in his time. The writer wrote the article Press for Children, in which he reflected about the role of translation in children's magazines. The researcher emphasized that translated works, on the one hand, "discovered the life of other nations," and on the other hand, they directed Ukrainian writers "in learning from world classics" [10].

Moreover, translating literature in exile could discover for young reader the world of another culture as well as the national identity of Ukrainian. It was its third role. Because the internal factors of the translated literature of Ukrainians abroad were to discover another culture and to find the national identity. Evidently, the choice of texts for translation was guided by the following conditions: first, the text had to be close to the moral, ethical, national and spiritual values of the Ukrainians, and to their idea of educational ideal; second, the artistic work needed to be popular in the "cultural world" as well as to be translated into different languages.

With the first condition is connected the issue of understanding, i.e. how the translator understands the author of the original text. It is met, when intentions and meanings of original and translation are the same. With regard to the second thought, it appears that Ukrainians wished to promote the Ukrainian language as distinctive and equal with others, and to attract the attention of children to reading the best books in their native language.

Primarily, Ukrainian writers in exile translated literature to promote their native language, which they called their mother tongue. In Ukrainian context, A. Horokhovych related three elements with language: national prestige, the soul of people, and their belonging to the family as well as the mother (that is why the Ukrainian language is called the mother's tongue) [9].

In particular, the publisher Yurii Teodorovych suggests in the preface of the translated book Gay Neck, the Story of a Pigeon by Dhan Gopal Mukerji that Ukrainian translation will help young adults to "learn more about the native language of Ukrainians, their nature and spirit" [11].

The book was translated by Stefaniia Nahorna and published in 1961 in Chicago, USA. It tells about interesting adventures and implements values such as humanity and brotherhood.

The two-volume edition of The Fairy Tales (1956 1958) by Wilhelm Hauff, published by the community "Tryzub" in Winnipeg, Canada, had the same aim. Reading these books, children of Ukrainian Diaspora could enlarge their Ukrainian vocabulary. In the fairy tale Little Muck, translators reproduced a teasing rhyme in Ukrainian styling. They used Ukrainian vocabulary 
and phraseology, reproducing it in the tradition of Ukrainian children's folklore (Fig. 4).

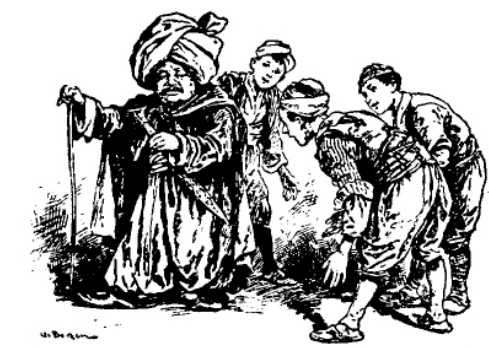

Як тільки він виходив на вулицю, то ми підіймали такий галас, аж в ухах лящало.

- Малий Мук! Малий Мук! - Ми навіть зложили про нього веселий вірш, який ми, бувало гуртом виспівували:

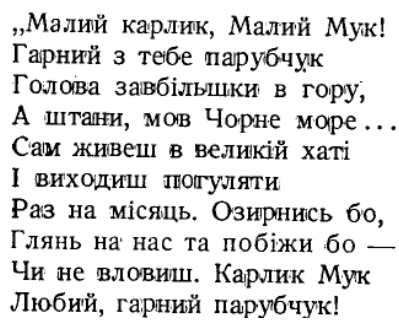

Fig. 4. The illustration of the fairy tale Little Muck by Wilhelm Hauff with a teasing rhyme

In their adaptations and translations, translators often used such Ukrainian culture-specific elements as common national lexis. Each fiction piece for children had a national styling, which intended to implement the educational idea with the regard to the native language and Ukrainian culture.

Factually, these artistic translations for children and youth were based on Ukrainian cultural tradition. Revealing before children previously unknown horizons and new cultures, the translators presented the experience through the Ukrainian national vision. Therefore, most translations for children are pervaded with the following motifs: (1) unity of the Ukrainians in the struggle for the historical Motherland; (2) the exile and search of a better fate. In general, Ukrainian Diasporic children's literature has these motifs.

The realization of the educational idea of respect to the national dignity of Ukrainians became the dominant for most translations of children's literature. It was achieved by addressing to the important topic of the struggle of Ukrainians for the independence of their own country, colonized during centuries.

Foreign fairy tales received reinterpretation in Ukrainian context. In particular, the novel Robinson Crusoe by Daniel Defoe is an adaptation, published by "Hoverla" in 1956, New York. According to aesthetic taste of the translator, the adaptation is "a didactic novel for young adults". The translator of this novel is M. Sydir-Chartoryiskyi, the author of works on educational issues and the founder of the publishing house. His translated novel has Ukrainian styling. In particular, Daniel Defoe is named Danyla. It is evident that Defoe's views on the reforming of society were close to the translator's, because the latter called the writer "a poet of truth and justice."

Ukrainian translation of animal stories by the English author Rudyard Kipling also has national particularities. There were translated two short stories from Kipling's collection The Jungle Book, namely the story about the boy or "man-cub" Mouwgli, published in Ukrainian in 1947 by the title Mouwgli's Fellows, and the story about the adventures of a valiant young mongoose, titled RikkiTikki-Tavi (1948). Here, the Ukrainian national features are highlighted with language codes such as "free", "kin", "struggle", etc. The translator actualized the motifs of unity, harmony, and conflict resolution between Ukrainians.

Ukrainian character is expressed in the short story Captain Daredevil (in French Le Capitaine Casse-Cou) by Louis Henri Boussenard translated in Ukrainian as The Fighters for Freedom ("Bortsi za Voliu", New York, 1965). Here, the translator, whose name is unknown, freely unfolds the plot of the original text. It is demonstrated even by the translated title of the writing.

If we compare the original and the translated texts, we can see a disparity. The original text portrayed a daredevil captain, who took part in the Boer War against the British rule. However, Ukrainian translation emphasized the struggle for freedom. Similar national struggle for Ukrainian independence occurred in 19171921. Therefore, this idea was the most important for Ukrainians in exile.

There are some analogies with Ukraine in the adaptation, particularly in the struggle of the Ukrainian people for their independence against various forms of colonization (economic, politic, cultural and language assimilation), which was described through the BoerEnglish war.

Such analogy demonstrates the map at the beginning of the adaptation (Fig. 5). The translator wrote: "Today the whole South Africa is colonized by England, though it has its own parliament and self-government. Now look up! There you will see our Black Sea and a strip of our motherland. It is Ukraine! Reading this book guess in it your Ukraine!" [12].

Similar ideas can be found in the collection The World of Big-Hearted Animals translated from English by Svitlana Kuzmenko and published by Ukrainian Women's Organization of Canada (Toronto, 1995). The fairy tales The Big-Hearted Moose Tidwick and The Clumsy Elephant by the American writers are translated close to the ideas of the desire of Ukrainians for their statehood and respect for national dignity.

V. Barahura highlighted the specifics of Kuzmenko's translations in his review of the mentioned book. The researcher emphasized that both short stories had implemented Ukrainian idea. In particular, the first story about the elephant reflected the ideas of "national value", and "unity of people in the nation, their strength of spirit." In the second fairy tale about the moose, Barahura reflected on the restoring of historical justice, and summarized: "The story reminds us about the historical fate of our nation, particularly the occupation of our mother land by the neighbors, lack of national unity, and the exploitation of our historical land. Four 
years ago, Ukraine finally got rid of the occupiers and proclaimed its independence. Since then Ukraine has been leading an independent national-state life among free nations" (taken from the collection of TsDAZU in Ukraine - The Central State Archive of Foreign Ukrainica).

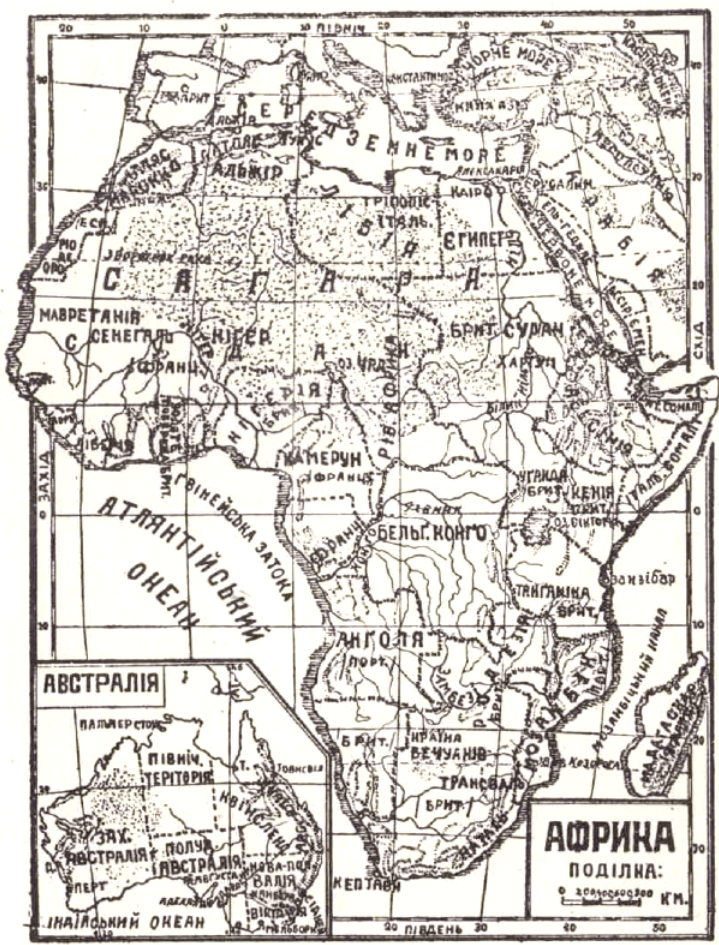

Це 6 мада Африки, того горячого краю, де 6 країна Бурів (Трансваль і Оранің). Шукайте тих країн вндау, на сході, це в в правого боку. кохоч морського берега. Ннн діла Південна Афрыка 6 дід владою Англі ру! Там побачите наше чорне Море і кінчвк нашого дорогого кран -Українв! Чвтаючи дю княжку, вгадайте і свою Україну!

Fig. 5. The illustration of a map from the translated book The Fighters for Freedom ("Bortsi za Voliu") by Louis Henri Boussenard

Another national issue is the returning to the Motherland. This sacred dream of the Ukrainians in exile is also implemented in their adaptations and translated works for children. The elder generation believed that Ukrainian Diasporic young adults would eventually return to the Motherland to make Ukraine independent. The novel for youth Little Lord Fauntleroy by the English-American writer Frances Hodgson Burnett (published in 1958, Winnipeg and translated by V. Litynska) also has similar motifs.

In the original, the author describes a character, young Cedric Errol who lives with his mother in New York City in genteel poverty. They are here in exile after the death of Cedric's father. Soon the boy returns to the "father's homeland" in England. There he must be a good master for his native land. Although the events happen in America and England, the Ukrainian reader perceives "his / her own" text: to follow the trade of the father and return to the motherland.

For Ukrainian Diaspora national and religious issues are interlinked. The works on religious issues highlighted the idea of Christian tolerance.
Significantly, Ukrainian Diaspora has given a special place to the issue of faith, adding it to the basic elements of Ukrainian spirituality. In particular, H. Vashchenko in The Traits of Our Human Ideal includes the following: "strong faith in God, the devotion to the will of God, faith in providence, humility, love for one's neighbor, honesty, truthfulness, loyalty to the oath, love for the Motherland, bravery, love for work and knowledge" (from archives of Ukrainian Free University, the collection by $\mathrm{H}$. Vashchenko).

Such senses fill Oscar Wilde's fairy tales. The fairy tales The Star-child and The Selfish Giant were translated by M. Lototskyi and published in 1947 by "Ukrainske Slovo" (Regensburg, Germany). The works promote such Christian virtues as kindness, mercy, and empathy. With the images of children, giants, beggars, and wizards are revealed the human vices of cruelty, indifference, selfishness, and pride.

The same as in the original text of The Selfish Giant, the translator shows the image of Jesus Christ and recreates the idea of atonement and paradise. However, the comprehensibility of the translation for Ukrainian reader is achieved through Ukrainian lexis and reproduction of the culture-specific elements. Even illustrations to the book have Ukrainian coloring and stylistics. Thus, children are portrayed in Ukrainian national clothing (Fig. 6).

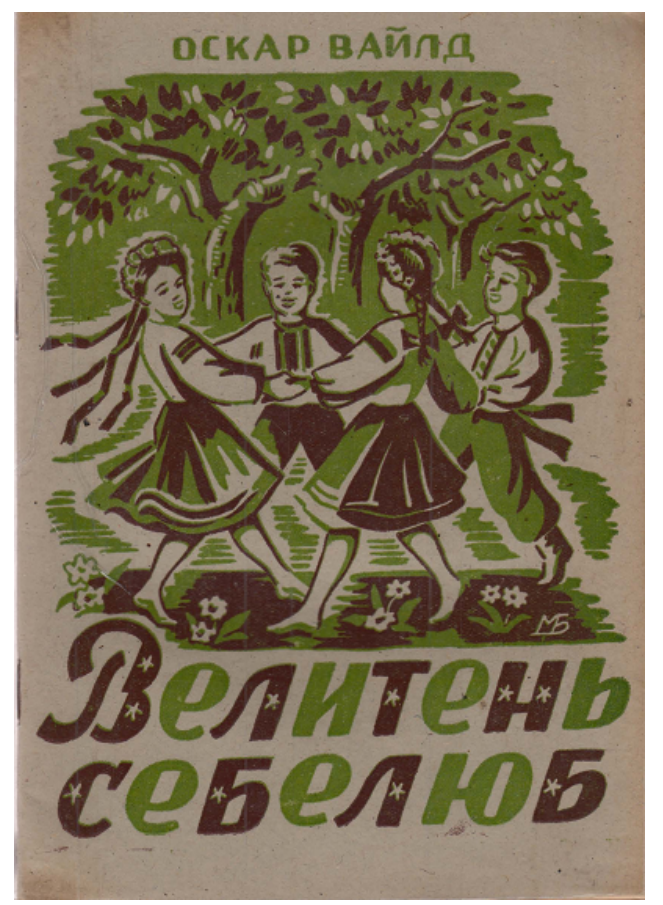

Fig. 6. The title of the translated book The Selfish Giant by Oscar Wilde

Both translated books were published in 1947 after the Second World War. At that time Ukrainian emigrants and other nations experienced the terrible impact of war. Therefore, the issues of charity, peace and tranquility in a human soul were relevant for Ukrainians and for the world in general, thus creating a new system of moral and ethical values. 
The issues of post-war period such as the traumas of war, fear, self-destruction and mental illness are discussed in the book Gay Neck, the Story of a Pigeon by Dhan Gopal Mukerji. The first edition in Ukrainian was published in Regensburg, Germany in 1947, and the second one, called in the preface by Y. Teodorovych as "the Nobel pedagogical and artistic work" was translated by S. Nahirna in 1961 .

Besides the purpose of learning the Ukrainian mother tongue, the translation discovers the Ukrainian attitude towards evil, hatred, war, courage, peace and truth in tune with the ideas of the Indian writer. The translation embodies the idea of solidarity, which is implemented through understanding of the traumatic experience of the other people as the result of the war. At the same time, the translator expressed the idea of creating "bridges" to overcome alienation and misunderstanding.

Already mentioned S. Kuzmenko in his other translation of the collection The World of Big-Hearted Animals creatively implemented the idea of tolerance. Each story is a story of another, distinguished by its otherness. Thus, the texts interpret the meaning of the uniqueness of each being. Relations between different cultures are realized in the idea of respect for different cultures.

The issue of respect for the kin and the family took the leading place in the system of moral and ethical values of Ukrainian Diaspora. The theme is interpreted by L. Bryzghun-Shanta in her free translations from English and French. The titles of the works are selfrevealing: The Beavers' Family, The Ducks' Family, and The Bears' Family. The main characters in her stories are families of animals or birds, and ducks even get the nickname Kachurovski (from Ukrainian "kachur", which means "duck").

There the author shows the habits of animals and birds, which distinguishes animal stories among other genres of children's literature. Through her small characters L. Bryzghun-Shanta highlights the issues of respect and reverence for elders, obedience of children, mastering the experience of adults. These issues reproduce the traditions of Ukrainian family upbringing.

\section{Conclusions}

To conclude, I emphasize that the principles of national and patriotic education were formed and implemented through the "concept of the educational ideal of the Ukrainian abroad".

1. The idea is based on the following principles: love for the native Ukrainian language and culture heritage; respect to the national and personal dignity of Ukrainians; respect and tolerance to the various cultures; Christian tolerance; ethical and moral values. They were at the center of the pedagogical reflections by H. Vashchenko, S. Rusova, O. Kulchytskyi, L. Biletskyi, A. Horokhovych, etc.

2. Particularly, the educational idea was implemented in translation of children's literature by such writers as Dhan Gopal Mukerji, Louis Henri Boussenard, Oscar Wilde, Daniel Defoe, Rudyard Kipling, etc. Such translations and adaptations are filled with the Ukrainian national colouring, including the names of heroes, common national lexis, passages from Ukrainian children's folklore, illustrations, etc.

3. Ukrainian translators have implemented the idea through the formula "universal values in the national sense." There was a specificity in translated children's literature. The Ukrainian native language or mother tongue, national dignity, Christian tolerance and cultural solidarity are those components of the educational ideal that are worth adoption by modern youth in Ukraine.

\section{References}

1. M. Gryshchenko (ed.), The New Ukrainian School (Ministry of Education and Science of Ukraine, Kyiv, 2016), https://mon.gov.ua/storage/app/media/zagalna\%20se rednya/Book-ENG.pdf. Accessed 21 Mar 2020

2. M. Vardanian, Svii - Chuzhyi v Ukrainskii Diaspornii Literaturi dlia Ditei ta Yunatstva: Natsionalna Kontseptosfera, Imaholohichni modeli (The Self - the Other in the Children's Literature of the Ukrainian Diaspora: National Sphere of Concepts, Imagological Models). (Dionat, Kryvyi Rih, 2018)

3. O. Dzhus. Science and Education. 10, 76 (2016)

4. H. P. Byhar, Dissertation, Yuriy Fedkovych Chernivtsi National University, 2006

5. C. Alvstad, in Handbook of Translation Studies, vol. 1, ed. by Y. Gambier, L. van Deorslaer (John Benjamins Publishing Company, Amsterdam, 2010), pp. 22-23

6. G. Lathey, in Routledge Encyclopedia of Translation Studies, ed. by M. Baker, G. Saldanha (Routledge, London New York, 2009), p. 33

7. O. Kulchytskyi. Ukrainian School. 5-6, 23 (1948)

8. B. Hoshovskyi, Ukrainska Dytiacha Literatura Sproba Ohliadu i Problematyka (An Outline of Ukrainian Children's Literature). (Ass'n of Ukrainian Writers for Children, Toronto, 1966)

9. A. Horochowych, Batky ta Dity (Parents and Children) (World Coordination Educational Council, Winnipeg Toronto, 1990)

10. B. Hrinchenko. We and Our Children 1, 261 (1965)

11. D.G. Mukerji, Pryhody Khorobroho Holuba (Gay Neck, the Story of a Pigeon) (Ukrainian - American Publishing and Printing Co., Chicago, 1961)

12. L.H. Boussenard, Bortsi za Voliu (The Fighters for Freedom). (OKO, New York, 1965). 